\title{
REVIEW OF MECHANICAL PROPERTIES OF OIL SHALES: IMPLICATIONS FOR EXPLOITATION AND BASIN MODELLING
}

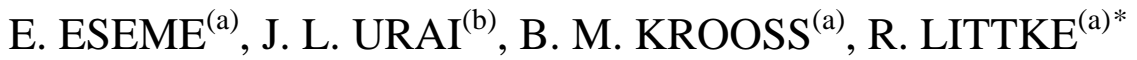 \\ (a) Institute of Geology and Geochemistry of Petroleum and Coal \\ RWTH Aachen University \\ Lochnerstr.4-20, D-52056, Aachen, Germany \\ (b) Structural Geology, Tectonics and Geomechanics \\ RWTH Aachen University \\ Lochnerstr. 4-20, D-52056, Aachen, Germany
}

\begin{abstract}
Mechanical properties of oil shales as a function of temperature and pressure are reviewed. Implications of evolution of these properties for in situ exploitation and basin modelling are explored. Mechanical properties at room temperature are well known. The existing data suggest a positive correlation between oil shale grade (organic matter content) and Poisson ratio, whereas tensile and compressive strength as well as modulus of elasticity show negative correlations. These properties are strongly affected by temperature. An increase in temperature results in loss of strength and decrease in Young's modulus. Strength follows a logarithmic decrease with increasing temperature, depending on grade. Creep is much enhanced by elevated temperature. Extrapolation of laboratory data to nature suggests that tensile fracturing may occur more easily during petroleum generation, and creep is more prominent in oil shales than in other rocks at this depth in the crust. More high-temperature experiments are required to validate these conclusions.
\end{abstract}

\section{Introduction}

The aim of this paper is to present a concise, up-to-date review of existing literature on mechanical properties of oil shales as a function of temperature and pressure. Such a review has not been presented for over twenty years. Based on an extensive survey, published literature data are summarized and integrated. The implications of this evolution to in situ exploitation are discussed in an attempt to extrapolate these observations to source rock burial and assess their potential use in basin modelling.

\footnotetext{
* Corresponding author: e-mail littke@lek.rwth-aachen.de
} 
Oil shales are usually rich in the liptinite maceral that yields commercial amounts of oil upon heating (retorting). Retorting comprises surface and in situ processes with many variants including the Petrosix, Alberta-Taciuk and Lurgi processes. Oil shale exploitation dates back to the $17^{\text {th }}$ Century [1] but yield and environmental problems have never allowed exploitation to compete with natural oil. As petroleum reserves decline, oil shales are becoming increasingly attractive as an alternative source of hydrocarbon fuel for three reasons. Firstly, vast resources, in excess of petroleum reserves, exist and most of them are already known. Secondly, most oil shales are buried at shallow depth $(<2 \mathrm{~km})$. Their exploitation therefore would require less sophisticated machinery and capital investment. Finally, unlike natural generation, expulsion and trapping where much petroleum is lost, careful exploitation may result in a higher relative yield. An inventory of known oil shale deposits is summarised by Dyni [2], while Brendow [3] discusses current shale oil production and niche applications of oil shale.

The main thrust of published research on mechanical properties of oil shale was done between 1970 and 1980 [4]. For the oil shales of the western US, the data available form a solid basis for the design of underground room-and-pillar mines. Mechanical properties at room temperature are well known, and correlation equations predict these properties from field observables [5-7]. The basis for the operation of underground retorts was established by measurements of mechanical properties at high temperature [8-11]. Compared to room temperature data, high-temperature data are far less abundant. This may be accounted for by i) the very complex material behaviour of oil shales at high temperature, ii) the much smaller number of tests conducted, and iii) the limitations of the available technology to conduct these experiments. Here, more data are definitely needed for reliable predictions of mechanical properties during retorting. In addition, extrapolation of the existing data to other oil shales worldwide is possible only in qualitative terms. After 1980, research on oil shale has focussed mainly on surface retorting in countries like Estonia, Japan and Israel $[12,13]$ with very little emphasis on mechanical properties.

\section{Composition, structure and occurrence}

Oil shales consist of minerals of variable composition mixed with organic matter commonly occurring finely dispersed in the matrix or in thin laminae. To allow an appreciation of their complex behaviour especially at high temperature, it is useful to consider an oil shale as a three-phase material. These phases (minerals, kerogen and pore fill) are sketched in Fig. 1. Bulk mechanical properties strongly depend on the volume fractions of these phases. Most studies on mechanical properties of oil shales are accompanied by an indication of organic matter content. Commonly, the parameter reported is the oil yield given in gallons per ton (GPT, $1 \mathrm{G}=4.2 \mathrm{~L}$ ) determined by the standardized Fischer assay technique (heating $100 \mathrm{~g}$ of crushed rock to $500{ }^{\circ} \mathrm{C}$ ). 


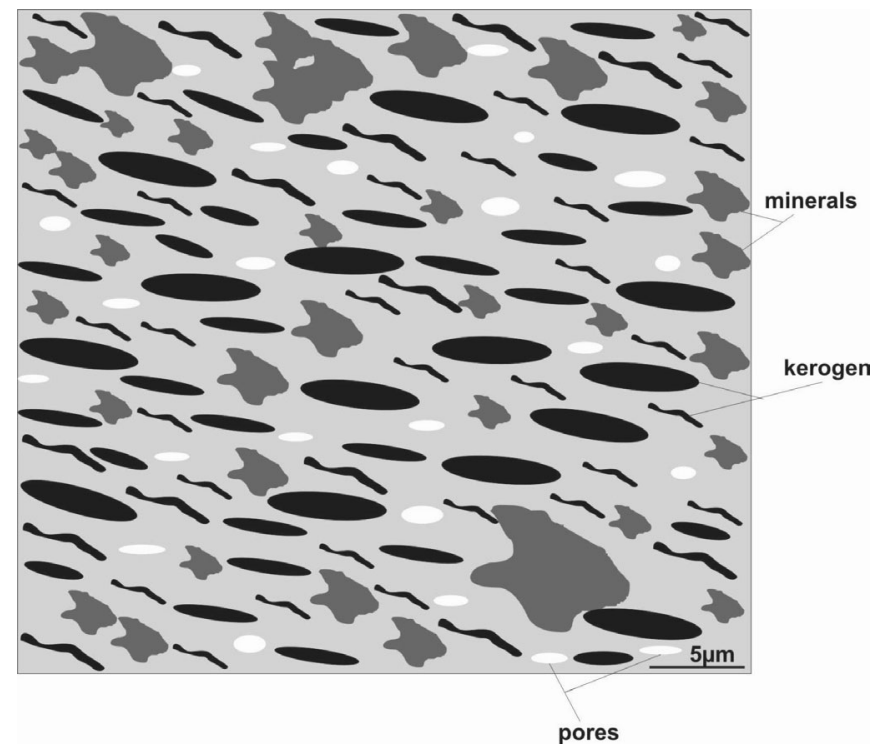

Fig. 1. Sketch illustrating the principal volumetric components of oil shales.

Oil shales are dominated by very fine-grained $(<2 \mu \mathrm{m})$ particles with varying amounts of silt $(2-60 \mu \mathrm{m})$ and fine sand $(>60 \mu \mathrm{m})$ as shown in Fig. 2 for the Posidonia shale from N. Germany. Porosity ranges from close to zero to over $30 \%$ with pore sizes dominated by $2-50 \mathrm{~nm}$ [14]. Low porosity is usually associated with high organic matter content, but mineral composition and diagenetic processes also have an effect. Intergranular

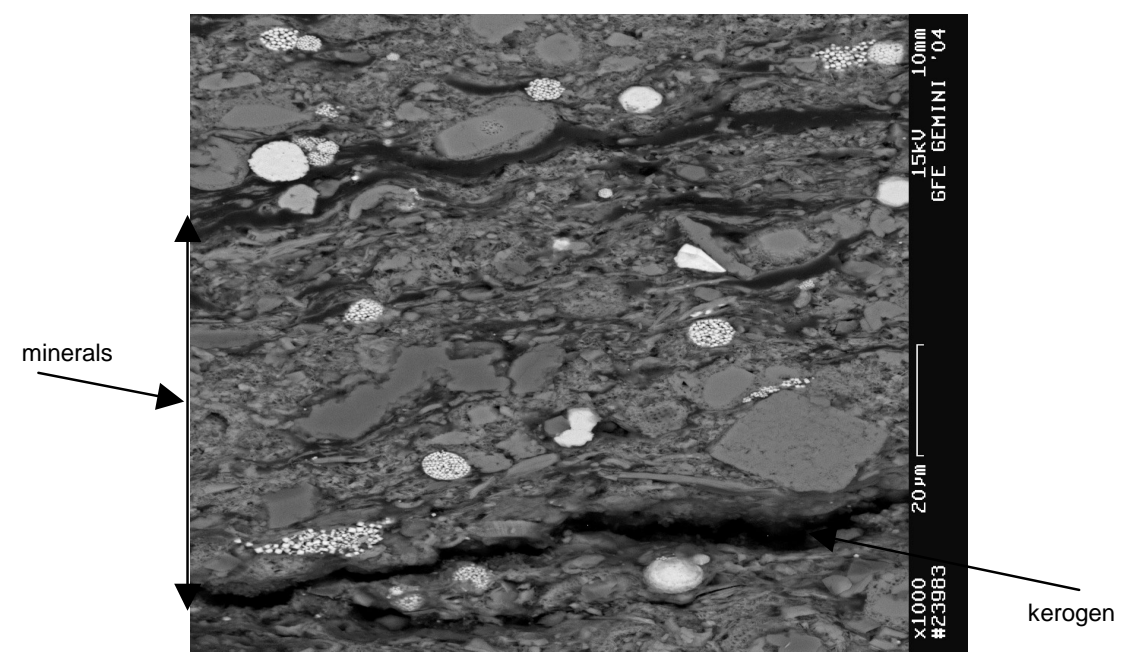

Fig. 2. Electron micrograph of the Posidonia shale from N. Germany showing lamination of organic matter and minerals. 
permeability of oil shales is mostly very low, due to very small pore sizes. Figure 1 shows that in the subsurface the overburden load is carried partly by kerogen and partly by minerals. Although Fig. 1 illustrates the main elements, microstructure is highly variable in oil shales occurring worldwide.

In addition to micro-lamination of organic matter and minerals (Fig. 2), macro-lamination is also common as seen from wireline logs and cores [15]. These layers may be laterally extensive with variation in properties due to compositional differences. For example, the Green River shale in Colorado can be subdivided into four zones including:

i) the clay zone in which the matrix is predominantly clay with very little carbonate;

ii) the saline zone that contains significant concretions of nahcolite $\left(\mathrm{NaHCO}_{3}\right)$ that decomposes upon heating;

iii) the leached zone where nahcolite has been diagenetically removed with the suggested consequence of increased intergranular permeability, and

iv) the dolomite-rich Mahogany zone that contains the most prolific oil shales [10].

In situ, some oil shales are reported to contain systematic, usually vertical fracture sets that may be regionally continuous. The vertical fractures point to tectonically relaxed areas [16] where the maximum principal stress is vertical[17]. In this setting, hydraulic fractures are expected to be vertical, too. However, for oil shales close to the surface where vertical and horizontal stresses are of similar magnitude, the anisotropy of tensile strength due to lamination of oil shales can be utilized to create horizontal hydro-fractures of significant lateral extent $[18,19]$. Horizontal fractures are also commonly observed in clay-rich oil shales that have experienced high overpressures [20].

\section{Relation of organic matter content to mechanical properties}

Figure 3 shows the relation between grain density and volume fraction of organic matter for six oil shales (Torbanite, Posidonia, Messel, Himmetoglu and Condor) studied by Eseme et al. [14]. The relationship is described by a linear equation similar to that given by Smith [21]:

$$
\text { Oc }=164.8-60.6 \rho_{\mathrm{m}},
$$

where Oc is the volume fraction of organic matter (in \%) and $\rho_{\mathrm{m}}$ is the grain density in $\mathrm{g} / \mathrm{cm}^{3}$.

For low-porosity shales of the US, this volume fraction of organic matter (Oc, \%) is related to oil yield (M, GPT) by Smith [21]:

$$
\mathrm{Oc}=(164.9 \mathrm{M}) /(\mathrm{M}+111.8) \text {. }
$$

Though this relation is expected to have a similar form for other oil shales and may be used to predict variation of their mechanical properties relative to organic matter content, it is only valid for the oil shales investigated. This 


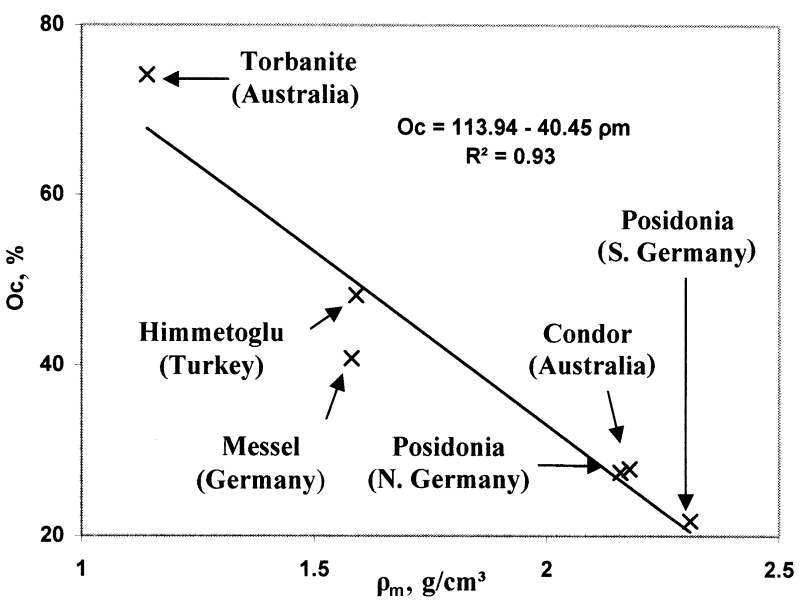

Fig. 3. Plot of grain density versus organic matter volume for six oil shales [14].

is because it depends on additional parameters including density and fraction of inorganic minerals (mostly between 2 and 3 but up to $5.0 \mathrm{~g} / \mathrm{cm}^{3}$ for pyrite). It also depends on density of kerogen (between 1.0 and $1.3 \mathrm{~g} / \mathrm{cm}^{3}$ ) as well as density of the oil generated $\left(0.7-0.9 \mathrm{~g} / \mathrm{cm}^{3}\right)$. Furthermore, it is affected by porosity (from very low to over $30 \%$ ) and conversion efficiency of kerogen depending on the retorting process. Oil shales contain types I and II kerogens which upon complete conversion may lose between 70 wt \% (type I kerogen) and $50 \mathrm{wt} \%$ (type II kerogen) [22].

Therefore, while knowledge of the organic matter content is important, the volume fraction that may be lost due to complete conversion and expulsion is another important factor. Figure 4 shows the grain density versus oil yield plot for some oil shales from the Western US studied by Agapito and Hardy [10]. The samples studied by Eseme et al. [14] of the grade calculated based on Equation 2 are shown for comparison in broken lines. Variations similar to those shown in Fig. 3 are discerned indicating that though a single equation is invalid for oil shales worldwide, both bulk and grain density decrease with increasing grade and organic matter volume.

At room temperature, most oil shales are hard and brittle with mechanical properties that are pressure-dependent and only weakly rate-dependent. Mohr-Coulomb- type constitutive equations are used commonly to evaluate mechanical properties at room temperature. The response to stress is correlated to grade, with ductile behaviour becoming more apparent as grade increases [4]. More advanced mechanical models that partly incorporate anisotropy of mechanical properties were also proposed for oil shales [23, 24]. However, loading rate is suggested to have some effect on compressive strength $[5,25]$ with samples tested at a low rate supporting lesser stress before failure. Tensile strength also correlates with grade and decreases with increasing organic content [11]. Though there is a general paucity of data 


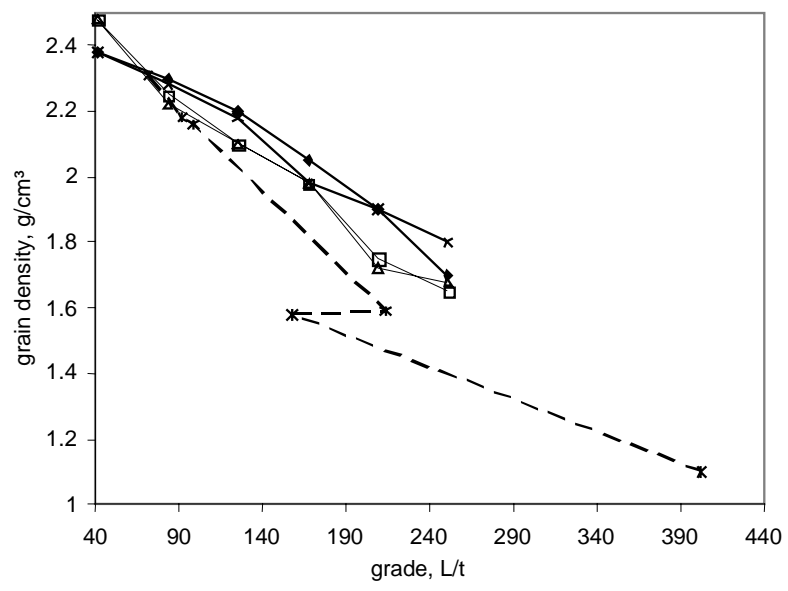

Fig. 4. Variation of density with grade in litres per ton (L/t) for oil shales from a range of localities in the Western US adapted from Agapito and Hardy [10] compared to oil shales from six locations studied by Eseme et al. [14].

related to fracture toughness of oil shales other than the investigation by Schmidt [26], Young et al. [27] suggest that fracture properties may show positive or negative correlations to grade depending on mineralogy of the rock. A number of workers also tested samples loaded in different directions and established that oil shales are transversely isotropic. Tensile strength is lowest perpendicular to bedding due to lamination [4].

Table 1 shows a summary of typical values for mechanical properties of two oil shales of different grade at room temperature, based on published measure-

Table 1. Mechanical properties of two grades of oil shales from the Western US at room temperature

\begin{tabular}{|l|c|c|c|}
\hline \multicolumn{1}{|c|}{ Property } & Unit & $\begin{array}{c}\text { Lean shale } \\
\text { (low-grade) }\end{array}$ & $\begin{array}{c}\text { Rich shale } \\
\text { (high-grade) }\end{array}$ \\
\hline Organic carbon content & $\mathrm{vol} \%$ & 20 & 50 \\
Oil yield & $\mathrm{L} / \mathrm{t}$ & 63 & 210 \\
Grain density & $\mathrm{g} / \mathrm{cm}^{3}$ & 2.4 & 1.8 \\
porosity & $\%$ & 0 & 0 \\
Young's modulus & $\mathrm{GPa}$ & $16 \pm 2$ & $4.5 \pm 0.5$ \\
& $\mathrm{MPa}$ & {$[10,23]$} & {$[10,23]$} \\
Unconfined & $125 \pm 25$ & $50 \pm 30$ \\
$\quad$ compressive strength & & {$[4,5,9,10]$} & {$[4,5,10]$} \\
Poisson's ratio & & 0.2 & 0.35 \\
& & {$[10]$} & {$[10]$} \\
Friction angle & & $40.5 \pm 0.5$ & 20 \\
& & {$[4,10]$} & {$[10]$} \\
Cohesion & $\mathrm{MPa}$ & $28 \pm 7$ & $28 \pm 7$ \\
& & {$[7,10]$} & {$[7,10]$} \\
Tensile strength & $\mathrm{MPa}$ & $13 \pm 1$ & {$[4,7]$} \\
& & {$[4,7]$} & {$[4.5$} \\
\hline
\end{tabular}


ments. All properties are strongly correlated to grade except for cohesion (C) and tensile strength $\left(\mathrm{U}_{\mathrm{T}}\right)$ which have similar values for both samples [4, 7]. Unconfined compressive strength (UCS) decreases with decreasing loading rate while Young's modulus (E) increases non-linearly with increasing confining pressure. The UCS and E decrease with increasing grade whereas, according to data by Agapito and Hardy [10], Poisson's ratio (v) shows an increase with grade at room temperature (Figs. 5, 6 and 7). Similar to the grain density data from Eseme et al. [14] shown in Fig. 4, UCS, E and $v$ also show variations that are not related to variations in grade but reflect differences in

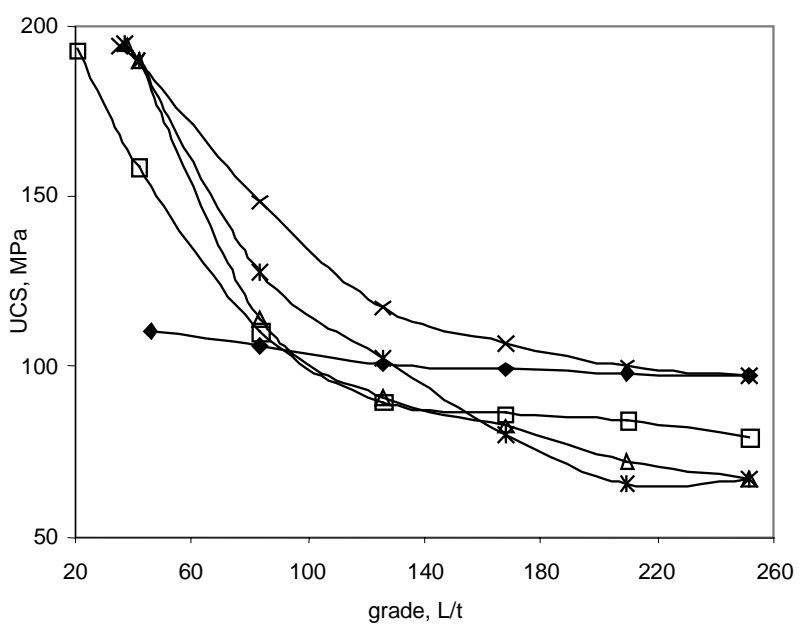

Fig. 5. Dependence of unconfined compressive strength on grade of US oil shales [10].

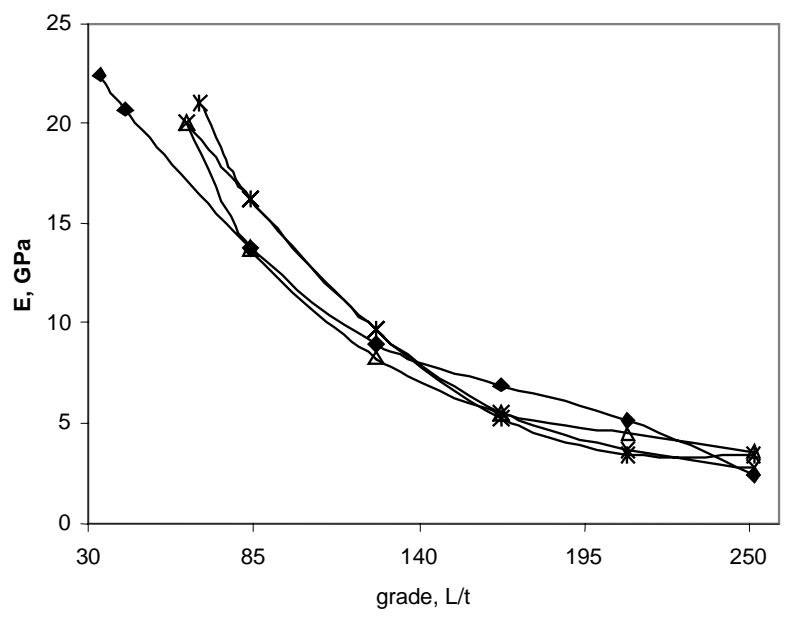

Fig. 6. Variation in modulus of elasticity with grade for oil shales from the Western US, based on data from Agapito and Hardy [10]. 


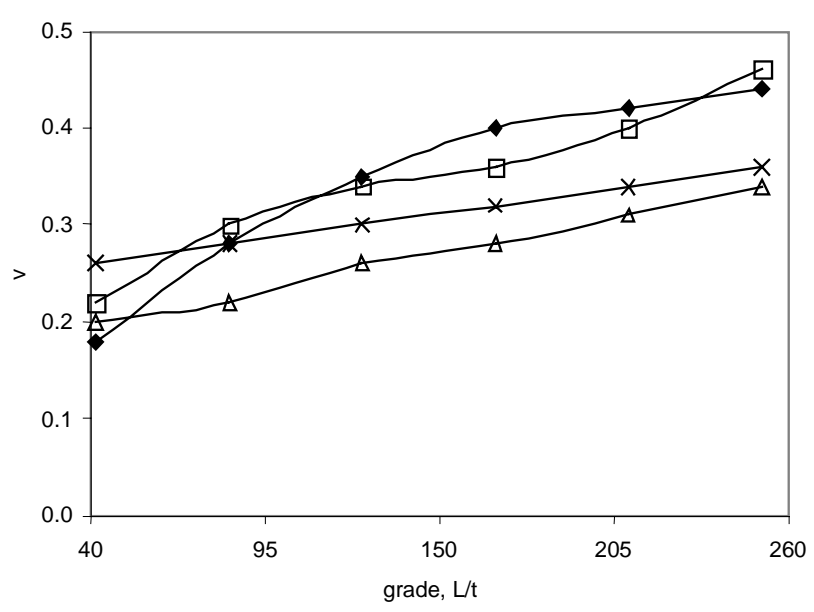

Fig. 7. Relation of Poisson's ratio to grade of oil shales from various locations in the Western US based on data from Agapito and Hardy [10].

composition and geologic history. Variations in the data from sub-samples of the same oil shale that are not related to grade are presumably due to variation in the properties (heterogeneity) of the organic matter.

\section{Evolution of mechanical properties with increasing temperature}

In in situ oil shales, most of the pores are either moisture- or air-filled. Upon heating, various forms of water (free and bound water) and light hydrocarbons vaporize and, at higher temperatures, kerogen deforms plastically and ultimately decomposes. After the initial expulsion of pore water and, possibly, some structured water from minerals such as smectite, and thermal decomposition of minerals such as nahcolite, kerogen yields more to deformation than most minerals. Bitumen from transformed kerogen may flow into pores depending on the kerogen distribution in the matrix and its proximity to pores. This results in a volume loss of the part of the load-bearing phase leaving only residual carbon after expulsion. The volumetric strain depends on initial porosity, organic matter content and type as well as mineralogy. The partial loss of the load-bearing phase is accompanied by decrease in tensile strength and elasticity modulus as well as in compressive strength.

Mechanical properties of oil shales therefore depend on both intrinsic and extrinsic factors. At the onset of heating, mechanical properties are affected by thermal expansion of minerals, softening of kerogen and development of pore pressure. At high temperature, the plastic flow of kerogen and its decomposition influence these properties. This is because kerogen decomposition generates porosity (and permeability) together with a pore fluid. The difference between these generation rates, in combination with the system's permeability evolution, determines the pressure of the pore fluid. Additional 
complications can arise from the presence of compounds such as nahcolite and lawsonite that decompose at temperatures below $450{ }^{\circ} \mathrm{C}$ leading to alterations of total porosity and pore pressure in a complex manner. Until now, almost all work to determine mechanical properties was empirical. These works attempted to fit a numerical model to data and estimate the magnitude of various terms using multiple linear regression analysis. While this technique identifies significant variables, the data are not readily amenable to a more refined mechanistic interpretation, and extrapolation to conditions outside the measured range is difficult.

Despite this complexity, a few general trends are evident. Strength, elastic moduli and acoustic velocities of oil shales decrease with increasing grade and temperature. Strength and acoustic velocities increase with increasing confining pressure. With increasing temperature, kerogen becomes much softer than the matrix minerals. Under a sufficient effective stress, this will lead to a strong tendency of kerogen to transform and flow into closely associated pores. In an anisotropic stress field, this leads to deformation with a large volumetric component of the strain tensor. At even higher temperatures, kerogen decomposes to yield hydrocarbons and a residue. In high-grade oil shales this means a significant volume loss of the part of the load-bearing phase with simultaneous generation of a pore fluid. Residual kerogen (coke) that may finally evolve to graphite with further increasing temperatures is sometimes reported to cause recementation of the minerals' grains.

Table 2 shows a summary of recommended values for mechanical properties of oil shales at elevated temperatures. With increasing temperature, these properties become increasingly difficult to describe using parameters like $\mathrm{E}$, UCS, C and $v$. All strength parameters decrease with increasing temperature. The effect of temperature on indirect (Brazilian) tensile strength for various oil shale grades from $23-232{ }^{\circ} \mathrm{C}$ [7] is shown in Fig. 8. It reveals a linear decrease of tensile strength with grade at the same temperature. For the same grade, the tensile strength decreases logarithmically with temperature. This holds also for the elasticity modulus as shown in Fig. 9 for oil shales of three different grades. Temperature increase beyond $150{ }^{\circ} \mathrm{C}$ leads to a thermally-activated softening of the kerogen and creep [28] that is positively correlated to grade and may be described by an Arrhenius-type equation [29]. The viscous component of deformation increases and mechanical properties become dependent on the rate of loading. Creep is affected by several factors including time, temperature, effective stress, porosity and organic matter content. In porous oil shales, a temperature-activated compaction occurs with porosity loss depending on matrix strength and corresponding decrease of permeability.

The second pair of columns in Table 2 summarizes mechanical properties of oil shales measured at $300{ }^{\circ} \mathrm{C}$. UCS and $\mathrm{U}_{\mathrm{T}}$ of the corresponding grades are lower than at $150{ }^{\circ} \mathrm{C}$ by a factor of two. Friction angle remains the same as at $150{ }^{\circ} \mathrm{C}$, while $v$ and $\mathrm{C}$ do not show much dependence on grade. At temperatures higher than $300{ }^{\circ} \mathrm{C}$, which is sufficient for partial decomposition of some kerogens, further softening of kerogen occurs accompanied by 
decrease of E (Fig. 9) even in initially non-porous oil shales. At these temperatures, the definition of elastic properties becomes problematic due to a rapid primary creep and dependence of Young's modulus on loading rate. Generation of petroleum in an undrained configuration raises pore pressure and causes embrittlement of oil shale with subsequent pressure release after expulsion. In addition, a volume strain at times proportional to the weight loss due to expulsion of water, inorganic and organic gases and oil may occur. Here, mechanical properties depend strongly on pore pressure and therefore on drainage conditions. If pore pressure increases faster than it can

Table 2. Mechanical properties of two grades of oil shales from the Western US at high temperatures

\begin{tabular}{|l|c|c|c|c|c|c|}
\hline \multirow{2}{*}{ Property } & \multicolumn{6}{|c|}{ Temperature } \\
\cline { 2 - 7 } & \multicolumn{2}{|c|}{$150{ }^{\circ} \mathrm{C}$} & \multicolumn{2}{|c|}{$300{ }^{\circ} \mathrm{C}$} & \multicolumn{2}{c|}{$450{ }^{\circ} \mathrm{C}$} \\
\hline Organic carbon content, \% & 20 & 50 & 20 & 50 & 20 & 50 \\
Oil yield, L/t & 63 & 210 & 63 & 210 & 63 & 210 \\
Young's modulus, GPa & $6.5 \pm 0.5$ & 5 & 1 & 0.5 & $<1$ & $<1$ \\
& {$[7,11]$} & {$[7]$} & {$[11]$} & {$[11]$} & & \\
Unconfined compressive & $45 \pm 5$ & 35 & 20 & 15 & 18 & - \\
strength, MPa & {$[7,11]$} & {$[7]$} & {$[9,11]$} & {$[11]$} & {$[9]$} & \\
Poisson's ratio & & & 0.3 & 0.3 & & $0.4 ?$ \\
& & & {$[10]$} & {$[10]$} & & \\
Friction angle, ${ }^{\circ}$ & 30 & 25 & 30 & 25 & 30 & $10 ?$ \\
Cohesion, MPa & {$[9,11]$} & {$[11]$} & {$[11]$} & & {$[9]$} & \\
Tensile strength, MPa & 10 & 7 & 7 & 5 & $5 ?$ & - \\
& {$[11]$} & {$[11]$} & & & & \\
& 4 & 2 & 2 & 1 & - & - \\
\hline
\end{tabular}

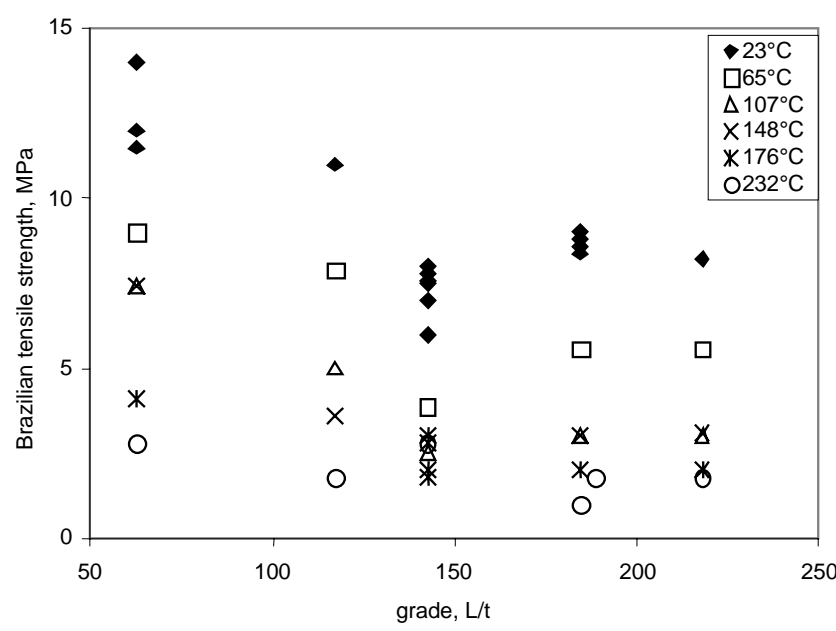

Fig. 8. Tensile strength vs grade showing the effect of increasing temperature between 23 and $232{ }^{\circ} \mathrm{C}$ [7]. 


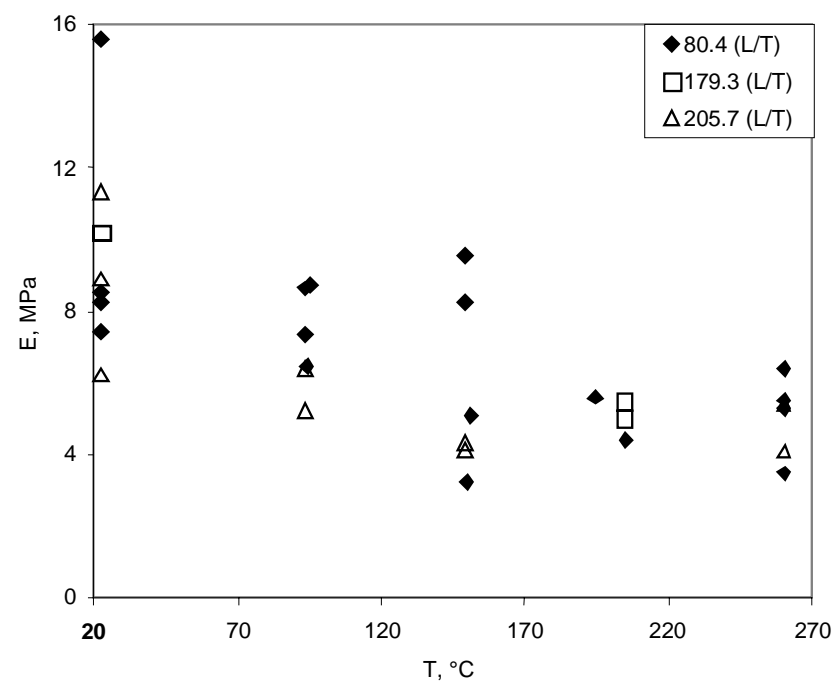

Fig. 9. Variation of elasticity modulus with temperature for three grades of oil shales [7].

be drained, initiation of fractures becomes possible similar to conditions in nature (e.g. Littke et al. [20]). If significant permeability remains after initial heating, hydrocarbons may flow through the intergranular permeability and the system will be drained.

The last two columns of Table 2 summarize mechanical properties of the two oil shales from the Western US at $450{ }^{\circ} \mathrm{C}$. Compared to room temperature, the data are much less well constrained. At this high temperature, the impact of confining pressure on compressive strength becomes erratic (Fig. 10). When

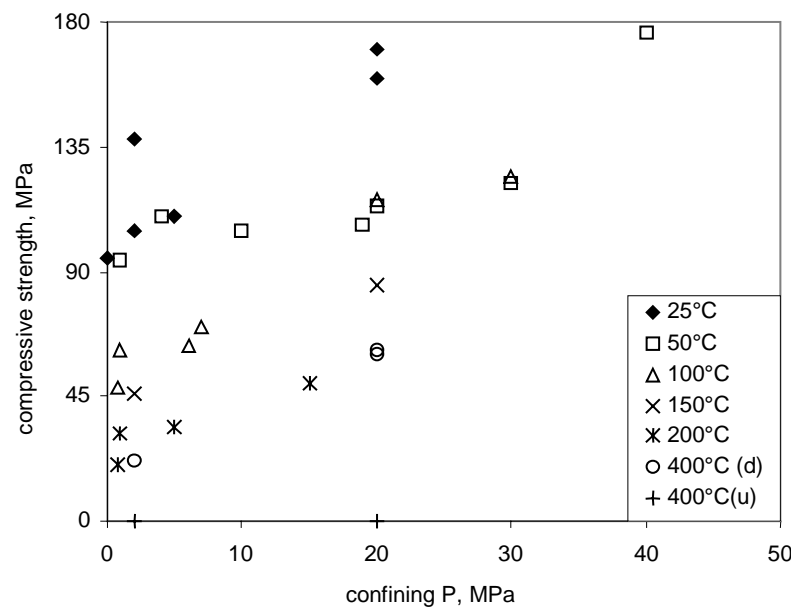

Fig. 10. Plot showing the effect of temperature on compressive strength in the presence of confining pressure [9]. Data points for $400^{\circ} \mathrm{C}(\mathrm{u})$ plot on the $\mathrm{x}$-axis. 
organic matter is heated to temperatures above $450{ }^{\circ} \mathrm{C}$, about $90 \%$ of the organic volume leaves the rock as oil vapour, non-condensable gas and water. The residual carbon is coked on the mineral matrix. Lean oil shales $(<125 \mathrm{~L} / \mathrm{t})$ due to the high volume of minerals can maintain their structure and leave a relatively strong residue after retorting. In contrast, rich oil shales (>167 L/t) lose much of their strength when the organic matter is decomposed. During heating to temperatures higher than $450{ }^{\circ} \mathrm{C}$, (up to $1200{ }^{\circ} \mathrm{C}$ in some experimental retorts) various reactions in the mineral matrix occur, such as decomposition of carbonates into oxides and carbon dioxide, synthesis of pyroxenes, formation of sulphur dioxide from pyrite etc. $[30,31]$.

\section{Implications for in situ exploitation}

For the design of in situ exploitation procedures, room temperature laboratory data can be used directly because the properties are not dependent on loading rate, and in situ vertical stress can be calculated based on the depth and density of oil shale. For the high temperature parts of the system, the laboratory data have to be extrapolated to the domain of in situ exploitation. Such extrapolations and the effect of temperature on tensile and compressive strengths are shown in Figs. 11 and 12, respectively. This extrapolation is expected to affect the property prediction in two important ways: firstly, creep strength will decrease according to the viscous component of deformation, and secondly, the evolution of pore pressure may be very different from that at laboratory

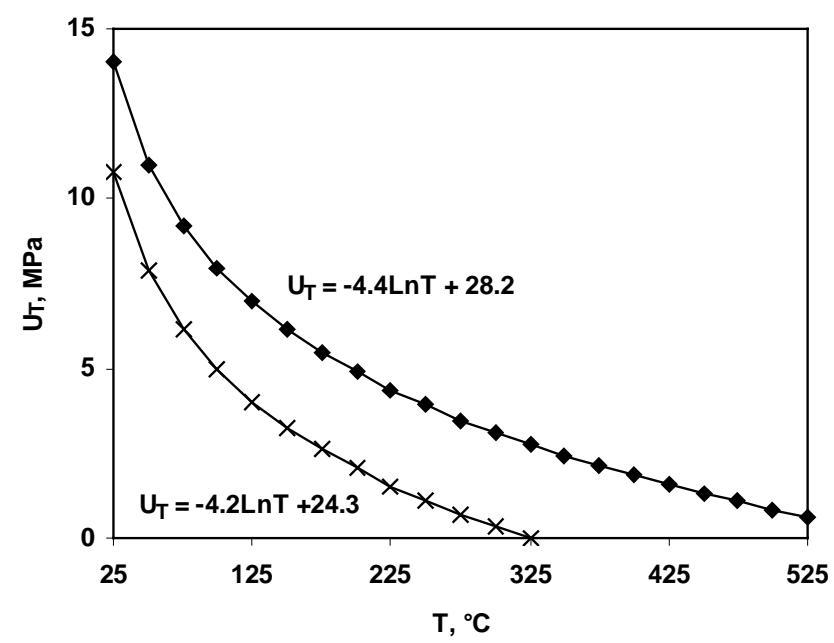

Fig. 11. Variation of tensile strength of 63 and $210 \mathrm{~L} / \mathrm{T}$ grade oil shales from

Tables 1 and 2 as a function of temperature showing logarithmic decrease relevant for prediction during in situ exploitation and assessment for basin modelling. 


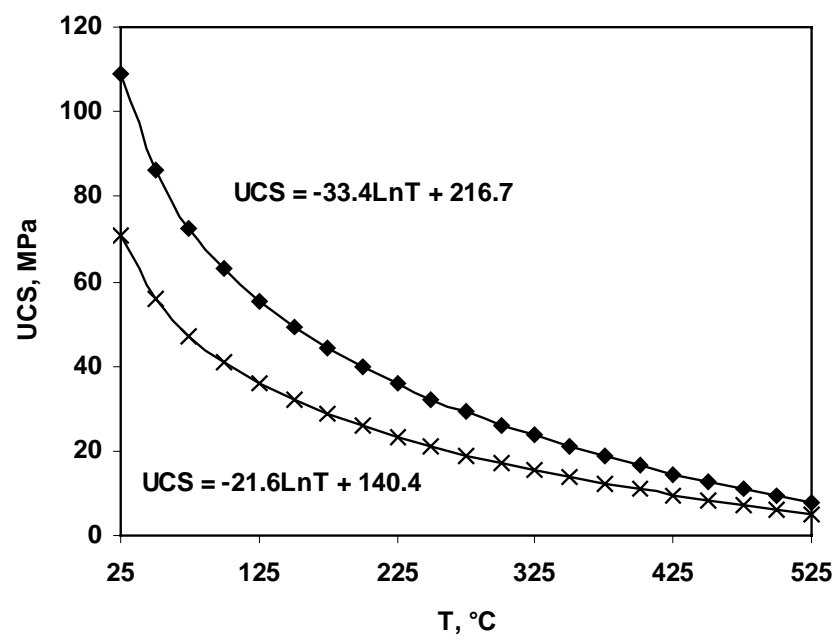

Fig. 12. Variation of unconfined compressive strength of 63 and $210 \mathrm{~L} / \mathrm{T}$ grade oil shales from Tables 1 and 2 as a function of temperature showing logarithmic decrease relevant for prediction during in situ exploitation and assessment for basin modelling.

rates, depending on initial permeability, rates of compaction and rates of pore fluid evolution. This will determine whether hydraulic fractures form and in which orientation.

\section{Implications for basin modelling}

In sedimentary basins, organic matter-rich rocks represent the source of oil and gas. With increasing temperature, generation of petroleum takes place between $80-180{ }^{\circ} \mathrm{C}$ [1]. These temperatures are lower than those used for retorting of oil shales, and rates of generation are correspondingly much lower, but occur over millions of years instead of days. Current models of sedimentary basins incorporate the kinetics of generation and expulsion of oil and gas, but without a detailed description of either the micromechanics of the process or the bulk mechanical properties of the source rocks during generation.

The mechanical properties reviewed in this paper give a first indication of these properties during generation from source rocks in nature (Figs. 11 and 12). Complications may arise, however, because, (i) the rates of heating in nature are much lower, and (ii) many source rocks contain significantly lower amounts of kerogen. Therefore, a simple extension of laboratory data to field conditions is problematic. Kerogen decomposition generates pore fluid and porosity and may be accompanied by increase in permeability and/or the generation of high overpressures. The difference between the rate of fluid and 
porosity generation together with the initial permeability and its evolution during generation determine the pore pressure of the system. In some cases, hydrofractures may form and provide rapid pathways for primary migration of oil. Unfortunately, the data reviewed in this paper provide little hard evidence of the rates of these processes in nature. The viscous component of creep in the kerogen at around $120^{\circ} \mathrm{C}$ at laboratory rates implies that at natural rates of deformation kerogen is much softer than in the laboratory at the same temperature. On the other hand, in most source rocks the kerogen content is lower than in oil shales, so that this aspect becomes less important.

\section{Conclusions}

A review of mechanical properties of oil shales was performed to evaluate the effect of temperature and pressure on these properties. The relevance of these data to in situ exploitation and basin modelling was explored. Room temperature data are quite extensive: deformation is dependent on stress but only weakly dependent on loading rate. The organic content is frequently expressed as oil yield and it is positively correlated to Poisson's ratio and negatively correlated to tensile and compressive strength, and modulus of elasticity. Although the trends are quite clear, the majority of data comes from the oil shales from the western USA, and properties of oil shales from other sources will have to be established if accurate properties are required.

Temperature drastically affects both compressive and tensile strength due to plastic deformation of kerogen accompanied by generation and expulsion of petroleum. In addition, temperature-activated creep of the kerogen phase and development of pore pressure due to generation of pore fluid and compaction are important processes. Future attempts to extrapolate the strength data to in situ exploitation and oil generation in nature would benefit from more experiments at lower deformation rates and temperatures at which generation and expulsion of petroleum occur. Because petroleum generation and expulsion occur at high temperatures, more data would enable evaluation of the relative contribution of kerogen to deformation as well as coupling of this deformation to petroleum expulsion.

\section{REFERENCES}

1. Tissot, B. P., Welte, D. H. Petroleum Formation and Occurrence. Springer. New York, 1984.

2. Dyni, J. R. Geology and resources of some world oil-shale deposits // Oil Shale. 2003. Vol. 20, No. 3. P. 193-252.

3. Brendow, $K$. Global oil shale issues and perspectives (Synthesis of the symposium on Oil Shale held in Tallinn (Estonia) on 18 and 19 November 2002 // Oil Shale. 2003. Vol. 20, No. 1. P. 81-92. 
4. Chong, K. P., Smith, J.W. Mechanical characterization of oil shale. In: Chong, K. P., Smith, J. W. (Eds): Mechanics of Oil Shale. Elsevier, 1984. P. 165-228.

5. Chong, K. P., Uenishi, K., Smith, J. W., Munari, A. C. Non-linear three dimensional mechanical characterization of Colorado oil shale // Int. J. Rock Sci. \& Geomech. Abstr. 1980. Vol. 17, No. 6. P. 339-347.

6. Chang, N.-Y., Bondurant, E. J. Oil shale strength characterization through multiple stage triaxial tests // Proc. 20th US Symposium on Rock Mechanics, Austin, Texas, 1979. P. 393-401.

7. Clossmann, P., Bradley, W. The effect of temperature on tensile and compressive strength and Young's modulus of oil shale // Soc. Petrol. Eng. J. 1977. AIME. SPE-6734, No. 52. P. 301-312.

8. Miller, R J., Wang, F.-D., DuBow, J. 1978. Mechanical and thermal properties of oil shale at elevated temperatures. In: J. H. Gary (Ed): Proc. 11th Oil Shale Symposium, Colorado School of Mines Press, Golden, 1978. P. 135-146.

9. Thigpen, L., Heard, H. C. Vertical stress distribution in oil shale aggregate columns during retorting // Soc. Petrol. Eng. J. 1979. Vol. 19, No. 2. P. 97-106.

10. Agapito, J., Hardy, M. Induced horizontal stress method of pillar design in oil shale // Proc. 15th Oil Shale Symposium, Colorado School of Mines, Golden, 1982. P. 191-197.

11. Zeuch, D. H. The mechanical behavior of Anvil Points oil shale at elevated temperatures and confining pressures // Canadian Geotechnical Journal. 1983. Vol 20, No. 2. P. 344-352.

12. Reinsalu, E. Eighty anniversary of oil-shale mining in Estonia// Oil Shale. 1996. Vol. 13, No. 3. P. 161-170.

13. Fainberg, V., Hetsroni, G. Research and development in oil shale combustion and processing in Israel // Oil Shale. 1996. Vol. 13, No. 2. P. 87-99.

14. Eseme, E., Littke, R., Krooss, B. M. Factors controlling the thermo-mechanical deformation of oil shales: implications for mudstone compaction and exploitation // Marine and Petroleum Geology. 2006. Vol. 23, No. 7. P. 715734.

15. Fertl, J. W. Evaluation of oil shales using geophysical well-logging techniques. In: T. F. Yen, G. V. Chilingar (Eds): Oil Shale, Elsevier, New York, 1976.

16. Olson, W. A. Stress relaxation in oil shale. In: Proc. 21st Symposium on Rock Mechanics, 1980. P. 517-520.

17. Smith, J. W., Chong, K. P. Introduction to mechanics of oil shale. In: Chong, K. P., Smith, J. W. (Eds): Mechanics of Oil Shale.Elsevier, 1984. P. 1-41.

18. Thomas, H. E. Hydraulic fracturing of Wyoming Green River oil shale: field experiments, phase I // US Bureau of Mines Report Investigation 7596, 1972.

19. Jensen, H. B. Oil shale in situ research and development// Talley Energy systems final report, US Department of Energy DOE/ LC/ 01791-T1, 1979.

20. Littke, R., Baker, D. R., Leythaeuser, D. Microscopic and sedimentologic evidence for the generation and migration of hydrocarbons in Toarcian source rocks of different maturities // Org. Geochem. 1988. Vol. 13, No. 1-3. P. 549559. 
21. Smith. J. W. Relationship between rock density and volume of organic matter in oil shales // Laramie Energy Research Center Report of Investigations 76/6, 1976.

22. Bordenave, M. L., Espitalié,J., Leplat, P., Oudin, J. L., Vandenbroucke, M. Screening techniques for source rock evaluation. In: Bordenave, M. L. (Ed): Applied Petroleum Geochemistry. Éditions Technip, Paris, 1993. P. 217-278.

23. Costin, L. S. Material properties of Green River oil shale// Report, Sandia National Laboratories, SAND81-1457, 1981.

24. Chen, W. F. The continuum theory of rock mechanics. In: Chong, K. P., Smith, J. W. (Eds): Mechanics of Oil Shale. Elsevier, 1984. P. 71-126.

25. Chong, K. P., Tumer, J. P., Dana, G. F. Strain rate effects on the mechanical properties of Utah oil shale. In: Mechanics of Structured Media, Part A. Elsevier, Amsterdam, 1981. P. 431-445.

26. Schmidt, R. A. Fracture mechanics of oil shale - unconfined fracture toughness, stress corrosion cracking and tension test results. In: Proc. 18th US Symp. on Rock Mech., Keystone, Colorado, 1977. P. 2A2-1 to ZA2-6.

27. Young, C., Trent, B. C., Patti, N.C. Stratigraphic variations in fracture properties. In: Chong, K. P., Smith, J. W. (Eds): Mechanics of oil shale. Elsevier, 1984. P. 291-335.

28. Chu, M.-S., Chang, N.-Y. Uniaxial creep of oil shale under elevated temperatures. In: Summers D. A. (Ed): Rock Mechanics, a state-of-the-art. Proc. 21st VS Symposium on Rock Mechanics, University of Missouri at Rolla, 1980. P. 207-216.

29. Means, D. W. Kinematics, stress, deformation and material behaviour // J. Struct. Geol. 1990. Vol. 12, No. 8. P. 953-971.

30. Smith, J. W., Robb, W. A., Young, N. B. High temperature reactions of oil shale minerals and their benefit to oil shale processing in place. In: J. H. Gary (Ed): Eleventh Oil Shale Symposium Proceedings, Colorado School of Mines Press, Golden, 1978. P. 100-112.

31. Patterson, J. H. A review of the effects of minerals in processing of Australian oil shales // Fuel. 1994. Vol. 73, No. 3. P. 321-327.

Presented by E. Reinsalu

Received March 27, 2006 